\title{
GROWTH OF JUVENILE MARINE SILVERSIDE (ODONTESTHES REGIA HUMBOLDT, 1821) (ATHERINIDAE) IN SEA NET PEN CAGES
}

\author{
CRECIMIENTO DE JUVENILES DE PEJERREY (ODONTESTHES REGIA \\ HUMBOLDT, 1821) (ATHERINIDAE) EN BALSAS JAULAS
}

\author{
Francisco A. Orellana \& Héctor E. Toledo \\ Departamento de Recursos Naturales y Medio Ambiente, Universidad de Los Lagos, Casilla 557, Puerto Montt, \\ Chile.Email. forellan@ulagos.cl; htoledo@ulagos.cl
}

\begin{abstract}
Juvenile silversides (Odontesthes regia Humboldt, 1821) reared in a sea net pen system performed well and adapted rapidly to this type of confinement. Values obtained for growth and mortality parameters in a period of 12 months, are similar to those observed in other marine fish cultured at industrial levels. The value of SGR obtained for the whole period (0.57), was similar to the value obtained in trials with juvenile rainbow trout using $20 \%$ replacement of fishmeal with white lupin meal (Lupino albus), over a period of 6 months ( $S G R=0.58$ ), but lower in relation to trials performed with red tilapia fry (Oreochromis aureus $\mathrm{x}$ Oreochromis niloticus) fed with coffee pulp diet (20\% fishmeal replacement) where SGR was 1.51, or when compared with Japanese seabass (Lateolabrax japonicus) fed with rations based on $30 \%$ fishmeal replacement with soybean meal $(\mathrm{SGR}=2.98$ ) over a 153 days trial. Mortality rate observed during the 12 months for the marine silverside reared in sea net pens, was in the range of typical values observed for rainbow trout reared in freshwater $(17,9 \%$ in 14 months), or for Atlantic salmon in freshwater (22\% from egg to smolt in 13 months); but lower in relation to mortality observed on Japanese seabass $(50.7 \%)$ and red tilapia (34,5\%), where the experimental period was about half of Odontesthes regia.
\end{abstract}

KEYwORDs: Juvenile growth, marine silverside, sea net pen cages.

\section{RESUMEN}

Juveniles de pejerrey de mar cultivados en un sistema de balsas jaulas se comportaron bien adaptándose rápidamente a este tipo de confinamiento. Los valores de crecimiento y mortalidad obtenidos en un período de 12 meses son similares a los observados en otros peces marinos cultivados a escala industrial. El valor de SGR obtenido para todo el período (0.57) fue similar al valor obtenido en ensayos con juveniles de trucha arcoiris, usando $20 \%$ de lupino blanco (Lupino albus) en reemplazo de harina de pescado para un período de 6 meses (SGR=0.58), pero inferior en relación a ensayos realizados con alevines de tilapia roja (Oreochromis aureus x Oreochromis niloticus) alimentados con pulpa de café (20\% de reemplazo de harina de pescado), donde el SGR fue 1.51, o inferior al compararlo con el mero japonés (Lateolabrax japonicus) alimentado con raciones en base a $30 \%$ de reemplazo de harina de pescado con harina de poroto soya ( $\mathrm{SGR}=2.98$ ) en un período de 153 días. La tasa de mortalidad observada durante el período de 12 meses para el pejerrey de mar cultivado en balsas jaulas, estuvo en el rango típico de valores observados para trucha arcoiris cultivada en agua dulce ( $17.9 \%$ en 14 meses), o para el salmón del Atlántico en fase de agua dulce (22 $\%$ de ova a smolt en 13 meses), pero mas baja en relación a la mortalidad de la perca marina japonesa (50.7\%) y de la mortalidad en tilapia roja (34.5\%), donde el período experimental fue alrededor de la mitad del período con Odontesthes regia (Humboldt 1821).

Palabras claves: Crecimiento de juveniles, pejerrey de mar, balsas jaulas. 


\section{INTRODUCTION}

The need to look for new horizons for Chilean aquaculture has driven the development of innovative projects, incorporating new technologies in existing processes or exploring the addition of exotic new species that are in high demand, with good international market values for the supply of farmed species. This is also true for native species that comprise the biological and food resources of the country. Therefore, the need to incorporate new cultured species is of enormous due to the overexploitation of resources that sustain the fisheries industry.

The marine silverside $O$. regia, is an atherinid highly appreciated in South America, especially in Peru and Chile where it is considered a fish of excellent gastronomic quality. In Chile this species has great importance for artisan fishermen, especially in the south austral macro-region ( $10^{\text {th }}$ and $11^{\text {th }}$ Regions), where landings represent $90 \%$ of the total caught in the country (Sernapesca 2000-2003).

The growth of fish is a process through which size (weight or length) increases with time and any attempt to depict or compare growth must consider both parameters. Growth in fish is characteristic, extending through their entire lifespan, although in its final stages growth is slower (Kinne 1960). The mode of fish grow can be explained through its entire life occuring in a fluid medium that supports them mechanically, enabling growth throughout the lifetime, limitations on length or weight are imposed more by biotic than by mechanical factors (Lagler 1985). Research on age and growth of O. regia is limited to that of Villavicencio \& Muck (1984) and Guevara-Carrasco et al (1991). There is no research on this species to be found in the literature regarding tanks or net pen cages. The aim of this study was to gather information on all aspects related to growth, and obtaining as much information as possible to establish future cultures of $O$. regia at industrial level.

\section{MATERIALS AND METHODS}

In this study, a population of 3,293 O. regia juveniles was utilized. They were obtained from a stock being reared in an experimental laboratory for native marine fish in Puerto Montt.
Fish were mantained in a sea net pen cage at pilot scale (4 x 4 x 4 metres; Fig. 1) in Chinquihue Bay, Puerto Montt (Lat. 42 $33^{\prime}$ S; Long. $73^{\circ} 12^{\prime}$ W) using the marine concession of Sea Salmon Ltd., alongside a set of commercial salmon net pens. Fish entered the sea cage with an average length of $13.88 \mathrm{~cm}$ and an average weight of $23.32 \mathrm{~g}$. Silversides were sampled monthly, on approximately the same date, over a 12 month period to measure total length and total weight. At the end of the period, 2,636 fish were alive (657 fish died during the 12 months period representing a $19.95 \%$ total mortality). Water temperature was recorded three times a day using an analogous thermometer.

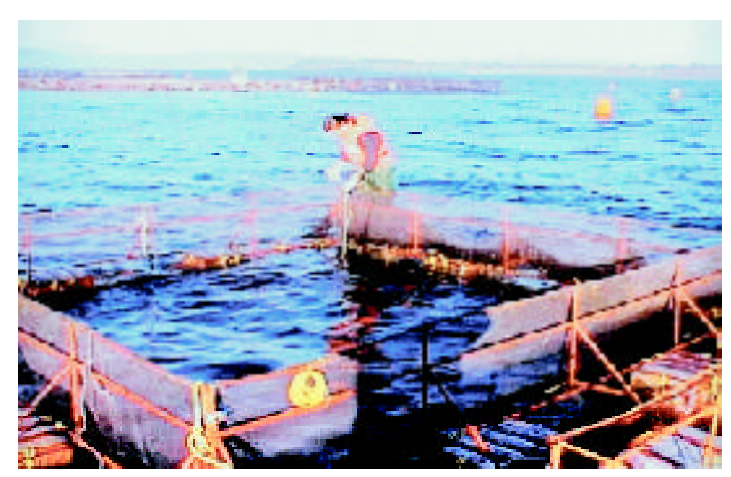

Figure 1. Experimental sea net pen for juvenile $O$. $r e$ gia.

Figura 1. Balsa jaula experimental para juveniles de $O$. regia

Feeding was performed twice dayly "ad libitum" with Royal pelletized food of different calibers (Trouw Suralim), increasing size as the fish gained weight and length. Data records were used to establish growth in length and weight graphs, Specific Growth Rate (SGR), relative condition factor and percentage of mortality. Averages and standard deviations for all measured parameters were included.

Numerical expressions of whole-body growth of fish may be based on absolute changes in length or weight (absolute growth) or changes in length or weight relative to the size of the fish being considered (relative growth). Measurements of growth expressed in terms of same interval of time (day, month, year) constitute a growth rate (Ricker 1979). For example if $t_{1}$ is the time at the beginning of an 
interval and $t_{2}$ the time at the end, and if $Y_{1}$ and $Y_{2}$ are the respective fish sizes at those times, then:

$$
\begin{array}{ll}
\text { Absolute growth } & =\mathrm{Y}_{2}-\mathrm{Y}_{1} ; \\
\text { Absolute growth rate } & =\left(\mathrm{Y}_{2}-\mathrm{Y}_{1}\right) /\left(\mathrm{t}_{2}-\mathrm{t}_{1}\right) ; \\
\text { Relative growth } & =\left(\mathrm{Y}_{2}-\mathrm{Y}_{1}\right) / \mathrm{Y}_{1} ; \text { and } \\
\text { Relative growth rate } & =\left(\mathrm{Y}_{2}-\mathrm{Y}_{1}\right) /\left[\mathrm{Y}_{1}\left(\mathrm{t}_{2}-\mathrm{t}_{1}\right)\right] .
\end{array}
$$

Relative growth and relative growth rate frequently are multiplied by 100 and expressed as percentages. These calculations imply a linear growth rate over the time interval. When growth rate is exponential, as it usually is over intervals of a year or less, growth should be expressed as an instantaneous rate. The instantaneous growth rate (G) is defined as the difference between the natural logarithms of succesive sizes over a unit of time, and the working formula is:

$$
\mathrm{G}=\left(\log _{\mathrm{e}} \mathrm{Y}_{2}-\log _{\mathrm{e}} \mathrm{Y}_{1}\right) /\left(\mathrm{t}_{2}-\mathrm{t}_{1}\right)
$$

Instantaneous growth rate also is frequently multiplied by 100 and expressed as percentage; then, it is more commonly called the Specific Growth Rate (SGR) and represents the percentage of body increase per day. Ricker $(1975,1979)$ provided detailed descriptions of these numerical expressions.
Growth in length data were adjusted linearly by plotting the regression line $(\mathrm{y}=\mathrm{a}+\mathrm{bx})$ by the least square method (Fig. 2) and weight data were adjusted exponentially by plotting the regression line $\mathrm{y}=\exp (\mathrm{a}+\mathrm{b})$ (Fig. 4).

SGR was calculated for growth in length and weight and it is shown together with average temperatures in Figures 3 and 5 respectively.

\section{RESULTS}

Average growth in length of juveniles of $O$. regia during the 12 months observation period was 9.44 $\mathrm{cm}$. Growth in length shows a sigmoid type of curve in the first stages and a linear relationship from day 200 onwards (Fig. 2). Monthly SGR in length reached a maximum value around day 130 , when fish had a total length of $16.5 \mathrm{~cm}$, from there on, tending to diminish and stabilize at lower values (Fig. 3). The temporal pattern of change in SGR in length was not associated with average values of water temperature. Temperatures showed a clear seasonal pattern reaching the peak value of $17.6{ }^{\circ} \mathrm{C}$ around day 250 during the summer period (Fig. 3).

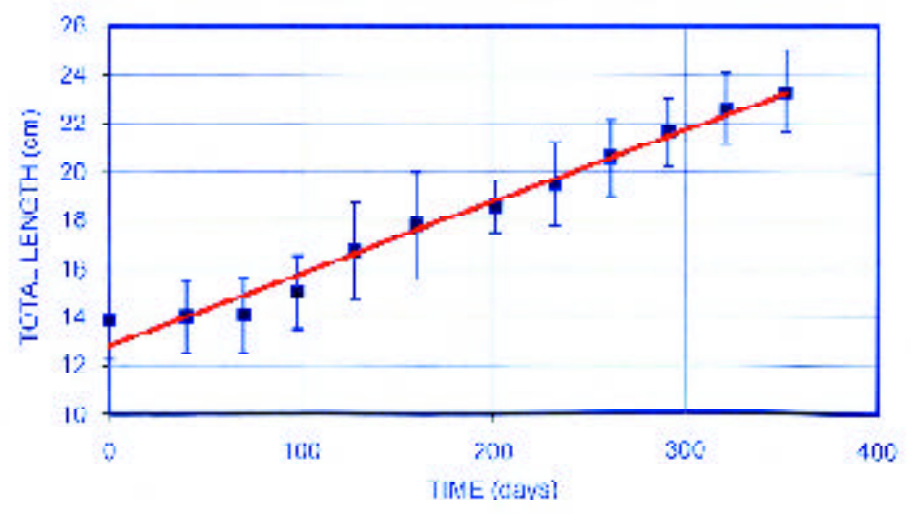

FIGURE 2. Average growth in length \pm 1 s.d. of juvenile $O$. regia reared in sea net pens (linear adjustment). $\mathrm{n}=663 ; \mathrm{y}=$ $12.8247+0.029621 \mathrm{x} ; \mathrm{r}^{2}=0.980695 ; \mathrm{p}<0.05$.

FIGURA 2. Crecimiento promedio en longitud \pm 1 d.s. de juveniles de $O$. regia cultivados en balsas jaulas marinas (ajuste lineal). $\mathrm{n}=663 ; \mathrm{y}=12.8247+0.029621 \mathrm{x} ; \mathrm{r}^{2}=0.980695 ; \mathrm{p}<0.05$ 
Growth of juvenile marine silverside: Orellana, F. \& H.E. Toledo

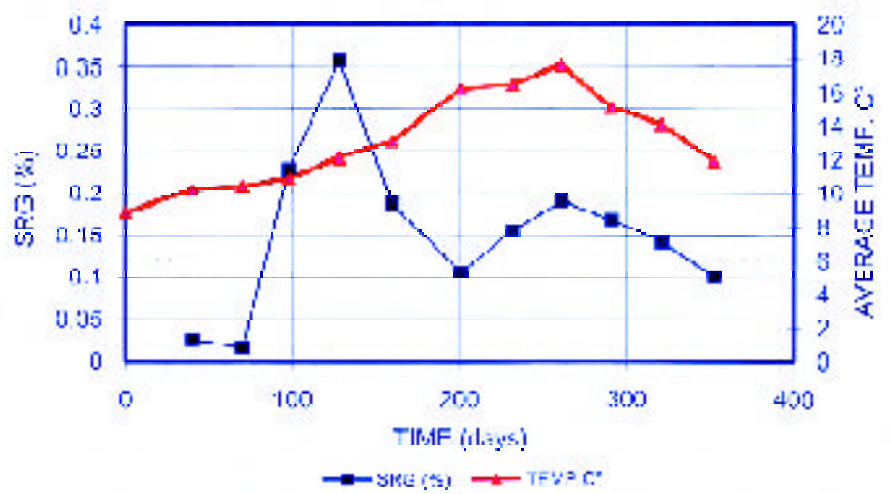

FIGURE 3. Monthly Specific Growth Rate (SGR) in length (\%/day) of juvenile $O$. regia reared in sea net pens and average water temperature $\left({ }^{\circ} \mathrm{C}\right) . \mathrm{n}=663$.

FIGURA 3. Tasa específica de crecimiento mensual (SGR) en longitud (\% diario) de juveniles de $O$. regia cultivados en balsas jaulas marinas y temperatura promedio del agua $\left({ }^{\circ} \mathrm{C}\right) . n=663$

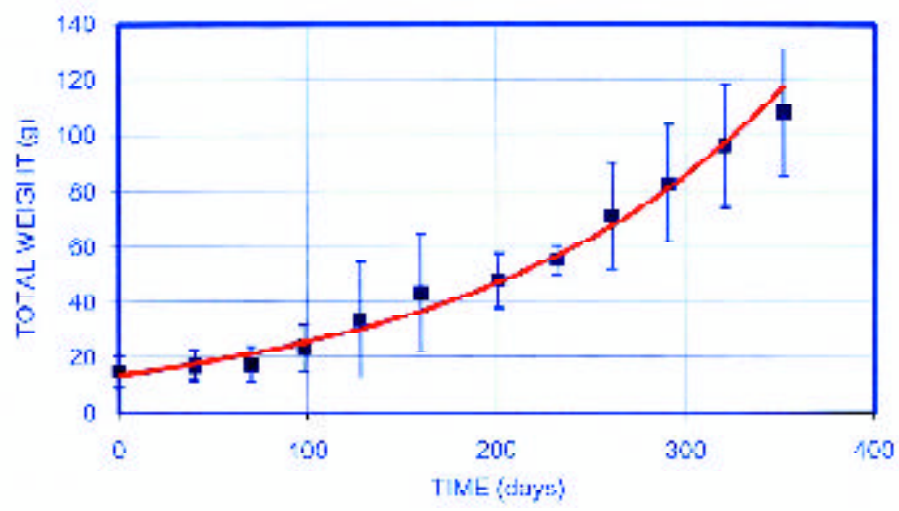

Figure 4. Average growth in weight \pm 1 s.d. of juvenile $O$. regia reared in sea net pens (exponential adjustment) n=663; $\mathrm{y}=\exp (2.62596+0.00607768 \mathrm{X}) ; \mathrm{r}^{2}=0.982672 ; \mathrm{p}<0.01$.

FiguRa 4. Crecimiento promedio en peso \pm 1 d.s. de juveniles de $O$. regia cultivados en balsas jaulas marinas (ajuste exponencial). $\mathrm{n}=663 ; \mathrm{y}=\exp (2.62596+0.00607768 \mathrm{x}) ; \mathrm{r}^{2}=0.982672 ; \mathrm{p}<0.01$ 
A similar curve is noted when observing growth in weight (Fig. 4). Initial and final length/weight values corresponded to $13.88 \mathrm{~cm} / 14.73 \mathrm{~g}$ and $23.32 \mathrm{~cm} /$ $108.09 \mathrm{~g}$ respectively. Initial and final total biomass were $48.5 / 284.9 \mathrm{~kg}$ and net increase was $236.4 \mathrm{~kg}$ in one year. Average growth in weight of juvenile $O$. regia for the 12 month period was $93.36 \mathrm{~g}$ (Fig. 4). Net increment in total biomass was $236.4 \mathrm{~kg}$ in one year (from 48.5 to $284.9 \mathrm{~kg}$ ), although mortality in the same period was $19.55 \%$ (1.79\% monthly average); this increment is equivalent to 5.87 times the initial biomass. Monthly SGR in weight showed a similar pattern to that presented by SGR in length, but with an additional increase around day 250 when maximum value in water temperature was reached (Fig. 5).

Relative condition increased as fish grew, from 0.5 to 0.85 (Fig. 7.) and no signs of sexual maturation were observed in the studied period. Water temperature showed a clear seasonal pattern with a maximum value in summer and diminishing in autumn and winter. Water temperatures ranged from $7.7^{\circ} \mathrm{C}$ to $20.1^{\circ} \mathrm{C}$ and monthly average was $13.9^{\circ} \mathrm{C}$.Geometric relationship between fish length and weight showed an allometric growth pattern. When data were transformed to linearize the relationship by plotting $\log _{e}$ (length) vs. $\log _{e}$ (Weight) and then adjusted linearly (geometric regression), the relationship appears to be isometric (Fig. 6).

Monthly average condition factor $(\mathrm{K})$ presented a linear increment in time with a $45 \%$ increase in one year (Fig. 7).

\section{DISCUSSION}

Juveniles reared in a sea net pen system performed well and adapted rapidly to this type of confinement. Values obtained in a period of 12 months for growth and mortality parameters are similar to those observed for other marine fish cultured at industrial levels (Angel 1977; Castillo et al 1996; Cremer \& Zhiang 1999; Uribe 1999). The value of SGR obtained for the whole period (0.57), was similar to the value obtained in trials with juvenile rainbow trout using 20\% replacement of fishmeal with white lupin meal (Lupino albus), over a period of 6 months (SGR=0.58; Toledo et al 2002), but lower in relation to trials performed with red tilapia fry (Oreochromis aureus x Oreochromis niloticus) fed with coffee pulp diet (20\% fishmeal replacement) where SGR was 1.51 (Castillo et al. 1996), or when compared with Japanese seabass (Lateolabrax japonicus) fed with rations based on $30 \%$ fishmeal replacement with soybean meal $(\mathrm{SGR}=2.98)$ over a 153 day trial (Cremer \& Zhiang 1999).

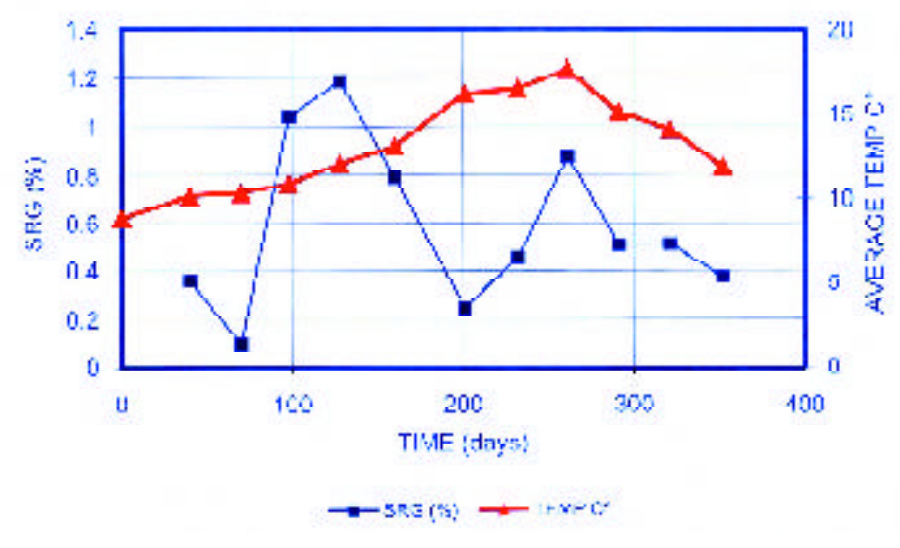

FIGURE 5. Monthly Specific Growth Rate (SGR) in weight (\%/day) of juvenile O. regia reared in sea net pens and average water temperature $\left({ }^{\circ} \mathrm{C}\right) . \mathrm{n}=663$.

FIgura 5. Tasa específica de crecimiento mensual (SGR) en peso (\% diario) de juveniles de $O$. regia cultivados en balsas jaulas marinas y temperatura promedio del agua $\left(\mathrm{C}^{\circ}\right) . n=663$ 
Growth of juvenile marine silverside: Orellana, F. \& H.E. Toledo

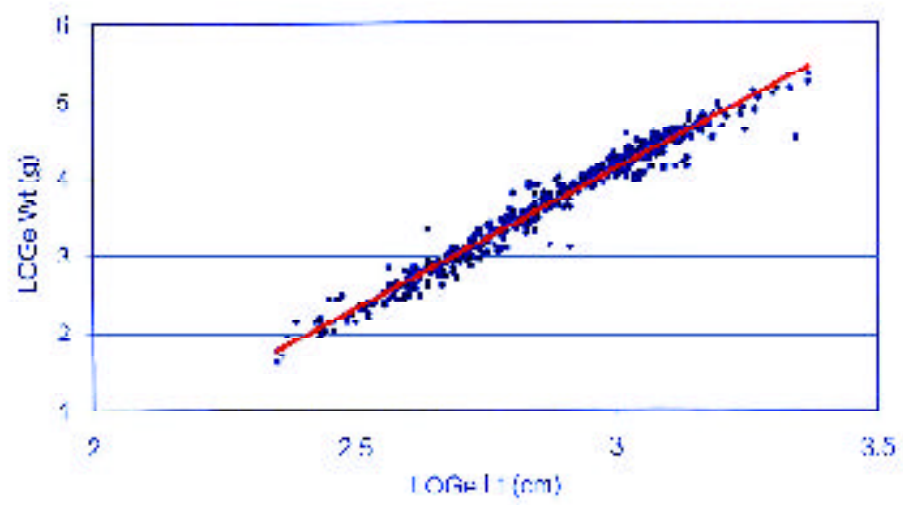

FIGURE 6. Relationship between $\log _{\mathrm{e}}$ length and $\log _{\mathrm{e}}$ weight of juvenile $O$. regia reared in sea net pens (linear adjustment); $\log _{\mathrm{e}}($ weight $)=-6.73936+3.61711 \log _{\mathrm{e}}$ (length) $\mathrm{n}=663 ; \mathrm{r}^{2}=0.971664 ; \mathrm{p}<0.01$.

Figura 6. Relación entre el $\log _{\mathrm{e}}$ de la longitud total y $\log _{\mathrm{e}}$ del peso total de juveniles de O. regia cultivados en balsas jaulas marinas (ajuste lineal). $\log _{\mathrm{e}}$ (peso) $=-6.73936+3.61711 \log _{\mathrm{e}}(\operatorname{largo}) ; \mathrm{n}=663 ; \mathrm{r}^{2}=0.971664 ; \mathrm{p}<$

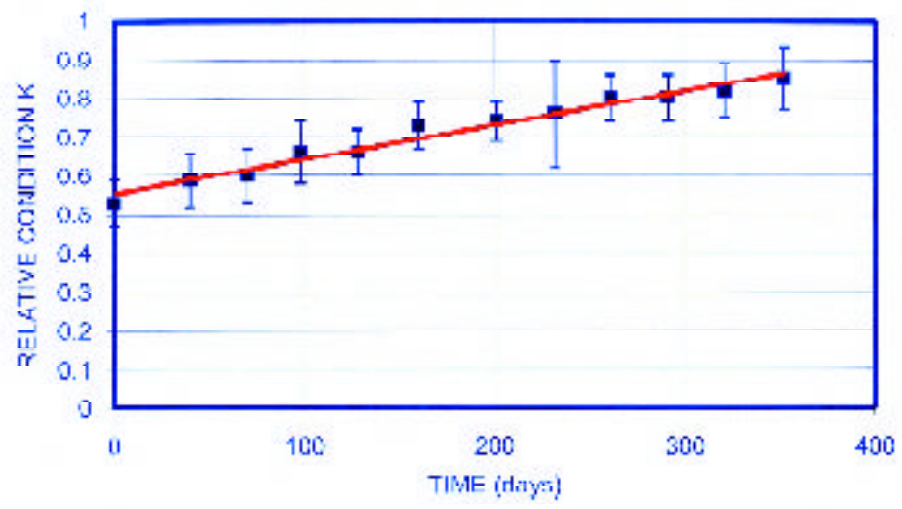

FIGURE 7. Monthly average condition factor $(\mathrm{K}) \pm 1$ s.d. of juvenile $O$. regia reared in sea net pens (linear adjustment). $\mathrm{n}=663 ; \mathrm{K}=0.554+0.000878$ (days) $\mathrm{r}^{2}=0.970515 ; \mathrm{p}<0.01$.

Figura 7. Factor de condición promedio mensual $(\mathrm{K}) \pm 1$ d.s. de juveniles de O. regia cultivados en balsas jaulas marinas (ajuste lineal). $\mathrm{n}=663 ; \mathrm{K}=0.554+0.000878$ (días); $\mathrm{r}^{2}=0.970515 ; \mathrm{p}<0.01$ 
Although the artificial food provided to the fish was not formulated especially for the marine silverside requirements but for salmonids, they grew at a rate typical for marine fishes and accepted artificial feeding with no problems. It is important to accomplish more research in the nutritional field in order to obtain diets especially adapted to meet the requirements of this species reared under these conditions.

Also important is to develop artificial food based on protein sources other than fishmeal, and much effort is being exerted in this direction (De Silva \& Anderson 1985; Coll 1986; Dabrowsky et al 1989; Murai et al. 1989; Lowel 1990; Barnabe 1994; Kaushick et al. 1995; Kaushick 1997; Tacon 1995; Castillo et al. 1996; Bardach et al. 1996; Lanari et al. 1998; Refstie et al. 1998; Bureau \& Cho 1999; Cremer \& Zhiang 1999; Alexis \& Nengas 2000). Feeds for fish in captivity generally contain high levels of fishmeal and since fishmeal is costly and of limited supply, it needs to be used more cautiously to improve the economic sustainability of fish farming.

The production of successful fish feed formulae that rely less on fishmeal requires accurate information on the nutritive value of more economical protein sources (Bureau \& Cho 1999). Alternative animal protein ingredients (blood meal, feather meal, offal meal, poultry by-products meal) are generally economical sources that have been used in fish culture for decades (De Silva \& Anderson 1985; Coll 1986; Barnabe 1994; Bardach et al. 1996).

Trash fish, fishery by-products, animal by-products and plant protein by-products have been used as replacement for fishmeal in artificial feed formulation. Vegetal sources of high protein content are aceptable alternatives to animal by-products since the former are available in theoretically unlimited quantities and their cost is low (Alexis \& Nengas 2000). Best results have been obtained with soybean meal, lupin meal, corn gluten meal, coffee pulp and cottonseed bran (Dabrowsky et al. 1989; Murai et al. 1989; Lowel 1990; Kaushick et al. 1995; Tacon 1995; Castillo et al. 1996; Lanari et al. 1998; Refstie et al. 1998; Cremer \& Zhiang 1999).

Mortality rate observed during the 12 month period for the marine silverside reared in sea net pens, was in the range of typical values observed for rainbow trout reared in freshwater $(17,9 \%$ in 14 months, Angel 1977), or for atlantic salmon in freshwater phase (22\% from egg to smolt in 13 months, Uribe 1999); but lower in relation to mortality observed in the Japanese seabass $(50.7 \%$, Cremer \& Zhiang 1999) and red tilapia (34,5\%, Castillo et al. 1996), where the experimental period was about half of Odontesthes regia.

\section{CONCLUSIONS}

Farming of the marine silverside from southern Chile in sea net pen systems is technically feasible.

Fish accepted artificial feeding with no problems, but this aspect could be improved by producing artificial feeds less dependent on fishmeal and especially adapted to meet marine silverside nutritional and energetic requirements.

Fish grew at a rate typical for marine fish exhibiting mortality rates similar to those observed in salmonids reared in freshwater but lower than red tilapia or japanese seabass.

\section{ACKNOWLEDGEMENTS}

We would like to thank to Mr. E. Sanhueza from Sea Salmon Ltd. for permitting the use of his company marine concession for this study; to the fisheries technicians Veronica Villegas and Leonardo Zuñiga for the field work and to Mrs. Veronica Bittner for the statistical analysis of the fish data.

\section{BIBLIOGRAPHY}

Alexis, M.N. \& I. Nengas. 2000. Current state of knowledge concerning the use of soy products in diet for feeding sea bass and sea bream. Needs for future research. Report National Centre for Marine Research, Athens, Greece, pp. 1-37.

Angel, C. 1997. Crecimiento de la trucha arcoiris (Oncorhynchus mykiss) en agua dulce. Seminario de Titulación, Universidad de Los Lagos, Puerto Montt, Chile.

Bardach, J.E., J.H. Ryther \& W.O. Mclarney. 1996. Acuacultura: Crianza y Cultivo de Organismos Marinos y de Agua Dulce A.G.T. Editor S.A., México, $741 \mathrm{pp}$.

BARnABE, G. 1994. Aquaculture: Biology and Ecology of Cultured Species. E. Horwood, N. York, 403 pp.

Bureau, D. P. \& C. Y. Cho. 1999. An introduction to 
Nutrition and Feeding of Fish. University of Guelph, Ontario, Canadá, Internal Report.

Castillo, E., Y. Acosta, N. Betancourt, E.B. Castellanos \& V. Совоs. 1996. Utilización de la pulpa de café en la alimentación de alevines de tilapia roja. $3^{a}$. Jornada Científica, Estación de Acuicultura, Manzanillo, Cuba, pp. 1-9.

Coll, M.J. 1986. Acuicultura Marina Animal. Ediciones Mundi-Prensa, Madrid, 670 pp.

Cremer, M.C. \& J. Zhiang. 1999. Sea Bass grow as fast on soybean meal-based rations. Impulse Magazine Organization, Online Protein News.

Dabrowsky, K., P. Poczyczynski, G. Kock \& B. Berger 1989. Effect of partially or totally replacing fishmeal protein by soybean protein on growth, food utilization and proteolytic enzyme activities in rainbow trout (Salmo gaiirdneri). New in vivo test for exocrine pancreatic secretion. Aquaculture, 77: 29-49.

De Silva, S. \& T.A. Anderson. 1985. Fish Nutrition in Aquaculture. Chapman and Hall, London, $319 \mathrm{pp}$.

Guevara-Carrasco, G., M. Harel \& S. Leshin. 1991. Crecimiento del pejerrey Odontesthes regia regia (Atherinidae) entre 1979-1989, en el litoral peruano. Resúmenes III Seminario Pesca Artesanal y III Reunión Desarrollo Costero Integrado, $98 \mathrm{pp}$

KaUSHICK, I.J. 1997. Recent developments in the nutrition and feeding of marine finfish of interest to the Mediterranean. INVE Conference, ALIIA Tradeshow, Thessalonik, Greece: pp. 1-14.

Kaushick, I.J., J.P. Cravedi, J.P. Lalles, J. Sumpter, B. Fauconneau \& M. Laroche . 1995. Partial or total replacement of fishmeal by soybean protein on growth, protein utilization, potential estrogenic or antigenic effects, cholerestomia and flesh quality in rainbow trout Onchorhynchus mykiss. Aquaculture, 133: 257-274.

Kinne O. 1960. Growth, food intake and food consumption in an europlastic fish exposed to different temperatures and salinities. Physiological Zoology, 33: 288-317.

Lagler H. 1985. Ictiología. AGT Editores, Sud América, $489 \mathrm{pp}$.

Lanari D., M. Yones, R. Ballestrazzi \& E. D'AGARO .1998. Alternative dietary protein sources (soybean, rapeseed and potato) in diets for sea bream. 8th International Symposium on Nutrition and Feeding in Fish, Las Palmas de Gran Canaria, Spain, pp. 145

LoweL R.T. 1990. Use of soybean products in diet for aquaculture species. ASA Technical Bulletin, Vol. AQ 21-90 6/7 pp. 16

Murai, T., H. Ogata, A. Villaneda \& T. Watanabe. 1989. Utilization of soy flour by fingerling rainbow trout having different body size. Nippon Suisan Gakkaishi, 55: 1067-1073.

Refstie, S., T. Storebakken \& A.J. Roem. 1998. Feed consumption and conversion in Atlantic salmon (Salmo salar) dried diets with fishmeal, extracted soybean meal or soybean meal with reduced content of oligosaccharides, trypsin inhibitors, lectins and soya antigens. Aquaculture, 162: 301312.

RICKER, W. E. 1975. Computation and interpretation of biological statistics of fish populations. Bulletin of Fisheries Research Board of Canada (191): $382 \mathrm{pp}$.

RicKeR, W. E. 1979. Growth rates and models. In Fish Physiology, Volume VIII, Hoar, W.S., D.J. Randall \& J.R. Brett. Academic Press.

SERNAPESCA 2000-2003. Anuarios estadísticos de pesca. Servicio Nacional de Pesca y Acuicultura, Chile, SERNAPESCA, Anuarios del 2000 al 2003.

TACON A.G. 1995. Fishmeal replacers: Review of antinurients within oilseeds and pulses. A limiting factor for the aquafeed green revolution. Feed Ingredients, Asia, Singapore.

Toledo M.I.; Olivares G. \& A. Soto. 2002. Reemplazo de harina de pescado por harina de lupino ( $L u$ pino albus) en alimentos extruidos para trucha arco iris. Resúmenes X Congreso Latinoamericano de Acuicultura, Santiago, Chile, pp. 33

URIBE P. 1999. Cultivo del salmón atlántico (Salmo salar Linnaeus, 1758) en agua dulce. Seminario de Titulación, Universidad de Los Lagos, Puerto Montt, Chile.

Villavicencio, Z. \& P. Muck. 1984. Estudio de otolitos de Odontesthes regia, pejerrey: determinación de edad. Boletín del Instituto del Mar del Perú, 8: 69-100. 